\title{
$\mathrm{ZnO}$ セラミックスの直流前課電による電気的特性 の変化とこれに及ぼす試料の熱処理効果
}

$\begin{array}{llllll}\text { 正員 河 } & \text { 村 } & \text { 英 } & \text { (昭城 大) } \\ \text { 准 } & \text { 員 } & \text { 田 } & \text { 勝 } & \text { (名城 大) } \\ \text { 正 員 } & \text { 縄 } & \text { 由 } & \text { 正 } & \text { (名城 大) } \\ \text { 正 員 } & \text { 家 } & \text { 田 } & \text { 正 } & \text { (愛知工大) }\end{array}$

\section{Effect of Heat Treatment on Degradation of Zinc Oxide Ceramics after DC Pre-stress}

Hideaki Kawamura, Member, Katsuhisa Yamada, Associate, Masahito Nawata, Member (Meijo University), Masayuki leda, Member(Aichi Institute of Technology)

Effects of heat treatment on degradation in the electrical properties of $\mathrm{ZnO}$ ceramics after DC pre-stress were investigated from the viewpoint of the time dependence of the leakage current under DC pre-stressing, the voltage-current $(V-I)$ characteristics, and the thermally stimulate current (TSC) before and after the DC pre-stressing.

For none heat-treated sample, the leakage current increases with the increase of the DC prestressing time. In this sample, the degradation of the $V-I$ characteristics observed and the new TSC peak observed at high temperature region after DC pre-stressing. The magnitude of this TSC peak is greater than that of the other TSC peaks. On the other hand, in the heat-treated sample at $600^{\circ} \mathrm{C}$, the leakage current decreases with the increase of the DC pre-stressing time. The current in $V-I$ characteristics decreases after the $\mathrm{DC}$ pre-stressing.

From these results, it is suggested that the effect of DC pre-stressing on the electrical properties for $\mathrm{ZnO}$ ceramics is changed remarkably by the heat treatment after sintered $\mathrm{ZnO}$ ceramics. These phenomena will be associated with the phase transition of the $\mathrm{Bi}_{2} \mathrm{O}_{3}-$ rich intergranular layer by heat treatment after sintered $\mathrm{ZnO}$ ceramics.

キーワード：ZnO セラミックス, 熱処理, 直流前課電, 直流漏れ電流, 電圧-電流特性, 熱刺激電流

\section{1.まえがき}

我が国における電力需要は都市部において急激に增 大している反面, 電力発生源はこの需要中心地から遠 隔化し，偏在化の傾向にある。従って，これらを結ぶ 電力系統は長大化し, 雷などの自然現象の脅威にさら される機会も多くなっている。一方，電気機器の電子 化や生産設備の自動化に伴うコンピュータ制御が進む につれて, 電気の質の向上, 高信頼化がより一層強く 望まれている。このような背景のもとで, 電子機器の
回路保護, サージ吸収，更には電源電圧の安定度を向 上させることを目的としてバリスタが，また雷サー ジ, 開閉サージの異常電圧を吸収し, 電力機器を保護 することを目的として避雷器が広く用いられている。

酸化亜鉛 $(\mathrm{ZnO})$ セラミックスは, 它の電気的に優れ た性能を生かして, これらバリスタ, 避雷器などの素 子として多く使用されている。これらの素子は優れた 非直線性の電圧一電流特性を示すことから，その避雷 器の構造は, 従来とは異なるギャップレス構造となっ ている。従って, 避雷器用の $\mathrm{ZnO}$ 素子には, 絶えず 
表 $i$ 試料の成分

Table 1. Amounts of additives in $\mathrm{ZnO}$ ceramics.

\begin{tabular}{c|c|c|c|c|c|c|c}
\hline 加物 & $\mathrm{ZnO}$ & $\mathrm{Bi}_{2} \mathrm{O}_{3}$ & $\mathrm{Sb}_{2} \mathrm{O}_{3}$ & $\mathrm{Co}_{2} \mathrm{O}_{3}$ & $\mathrm{Cr}_{2} \mathrm{O}_{3}$ & $\mathrm{MnO}_{2}$ & $\mathrm{SiO}_{2}$ \\
\hline$(\mathrm{mol} \%)$ & 95.5 & 0.7 & 1.2 & 0.7 & 0.5 & 0.5 & 0.5 \\
\hline
\end{tabular}

采統電圧が印加された状態となっており，微弱ではあ るが $\mathrm{ZnO}$ 素子の抵抗成分に対応した漏れ電流が流れ， それが熱暴走に至る要因とされている。このような電 圧印加に上る $\mathrm{ZnO}$ 素子の劣化に関しては多くの研究 報告がある(1)(2)が，長時間課電による特性の変化と焼 結後の試料の熱処理効果との相関性については明らか でない。

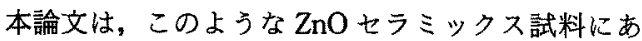
らかじめ直流電圧を印加し，このとき流れる漏れ電流 の時間的変化とその後に測定した電圧一電流特性, 熱 刺激電流などの電気的特性に及心直流前課電の影響 と熱処理効果について調べたものであり，それらの結 果を $\mathrm{ZnO}$ 素子の結晶構造とキャリヤの振舞いから検 討を加えている。

\section{2. 詿料の作成}

酸化重鉛セラミックス試料(以降， $\mathrm{ZnO}$ 試料とい う)としては，表 1 に示すように高純度の $\mathrm{ZnO}$ 成分に 6 種類の金属酸化物を微量添加して混合し, $1,200^{\circ} \mathrm{C}$ の高温度で焼結した試料(以降，基礎試料という)とこ の基礎試料を再び任意の温度(熱処理温度: $T_{H-T}=$ $450 \sim 900^{\circ} \mathrm{C}$ ) で加熱した熱処理試料の，2 種類を作成 した。

以上の試料はディスク状(值径 $33 \mathrm{~mm}$ )で，その表 面はNo. 0 番 $(57 \mu \mathrm{m})$ のサンドペーパから研摩を始 め, 最終的には $\gamma-\mathrm{Al}_{2} \mathrm{O}_{3}(0.06 \mu \mathrm{m})$ を用いて仕上げ， 厚さを約 $1 \mathrm{~mm}$ とした。その後，研摩した試料面に金 真空蒸着(直径 $18 \mathrm{~mm}$ ) し電極とした。

\section{3. 実験 方 法}

〈3・1〉直流前課電による漏れ電流基礎試料お よび熱処理試料をそれぞれ図1の回路図中に示した真 架恒温槽内の電極間に配置し，スイッチ $S$ を $a$ 側に 倒し, 試料温度 $T_{p s}=90^{\circ} \mathrm{C}$, 印加電死 $V_{p s}=200 \mathrm{~V}$ の 条件で直流前課電を行った。そして、このとき流れる 漏れ電流の時間的変化を測定した。

$\langle 3 \cdot 2\rangle$ 電圧-電流特性 直流前課電後, 試料温度 を室温に降温して以下の方法で電圧一電流特性を求め た。まず，試料温度を一定の状態として種々の大きさ の電圧を印加し，この印加電圧の大きさに対する電流

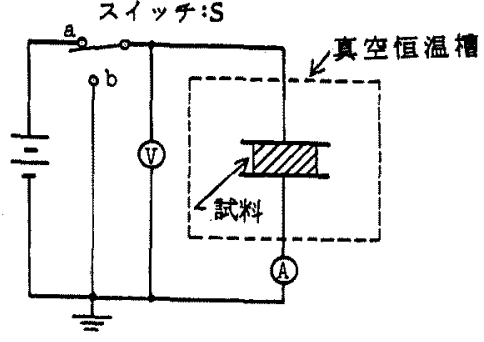

図 1 測定装置の略図

Fig. 1. Schematic diagram of the apparatus for the measurement.

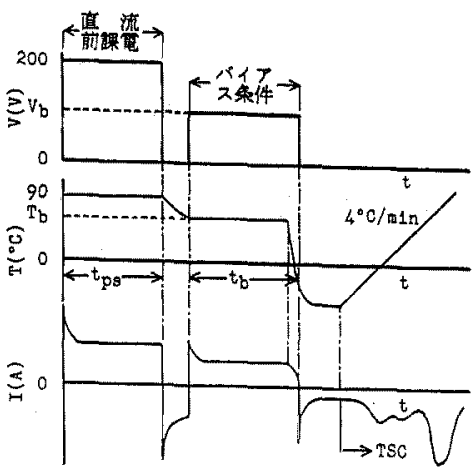

図 2 直流前課電と TSC の測定手順

Fig. 2. DC pre-stressing and procedure for measuring TSC.

の変化，すなわち，電圧一電流特性を測定した。この とき流れる電流は, 電圧印加後, 大きな吸収成分が流 れ, 時問の経過と共に減少して一定值となる。従っ て，V-I特性の電流值としては, 電圧を印加して 6 分後の值を用いている。次に, 試料温度を変化して同 様の実験を行った。

〈3・3〉熱刺激電流の測定 直流前課電後, 任意 のバイアス条件のもとで熱刺激電流(以降，TSC と略 記)の測定を行った。試料を任意の規定温度（以降，バ イアス温度 $T_{b}$ という)に保った後, 高圧側電極に正 極性の直流電压(以降，バイアス電圧 $V_{o}$ という)を規 定の時間(以降，バイアス時間 $t_{b}$ という)印加した。 その後, $V_{b}$ 印加の状態で試料温度を $T_{b}$ から $-80^{\circ} \mathrm{C}$ まで冷却してスイッチ $S$ を $b$ 側に倒し，電極間を短 絡して試料のエレクトレット化を行った。このとき振 動容量形微小電流電位計には $V$ 。印加時とは逆向きの 放電電流が流れる。この電流は時間と共に徐々に減少 してほほ一定となる。その後，電極間は短絡状態で試 料を $4^{\circ} \mathrm{C} / \mathrm{min}$ の一定昇温速度で加熱し，このとき流 
れる電流，すなわち TSCを測定した。図 2 は以上に 述べた測定手順の概要を示したものである。

\section{4. 実験結果および検討}

$\langle 4 \cdot 1\rangle$ 直流漏九電流図 3 は, 各試料の直流前 課電 (条件： $\left.T_{p s}=90^{\circ} \mathrm{C}, V_{p s}=200 \mathrm{~V}\right)$ により流れる電 流の時間的変化を示した一例である。漏れ電流の大き さおよびその時間的変化は, 試料の熱処理の有無とそ の温度によって著しく異なっている。熱処理を施して いない基礎試料では, 直流漏れ電流は直流電圧の印加 時間が長くなるにつれて指数関数的に増加する傾向を 示し,ついには熱暴走に至ることを示唆している。こ れに対して, 熱処理を施した試料では, 熱処理温度に よってその傾向が異なっている。すなわち， $600^{\circ} \mathrm{Cで}$ 熱処理した試料の直流漏九電流は, 電圧印加後 500 時

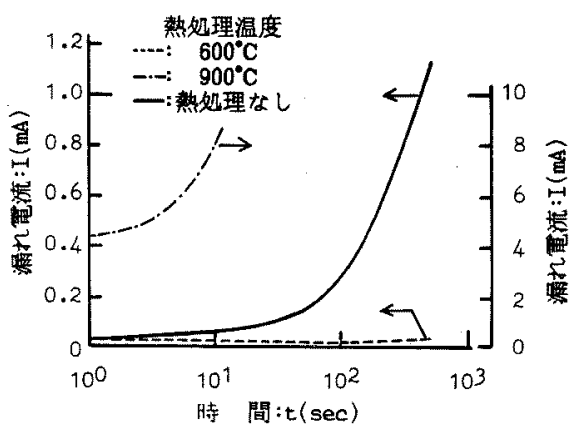

四 3 直流前課電による漏孔電流の変化

Fig. 3. Dependence of leakage currents on DC pre-stressing time.

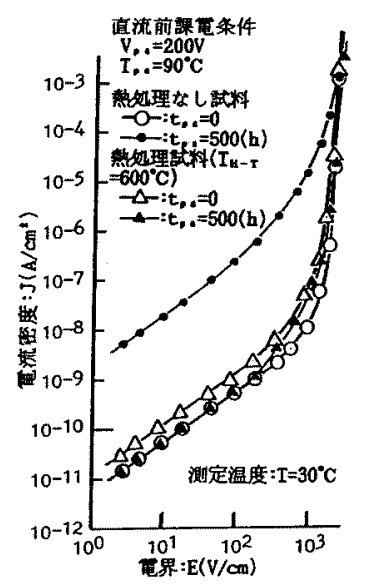

図 $4 \quad E-J$ 特性に及浑す直流前課電の影響 Fig. 4. Effect of DC pre-stress on $E-J$ characteristics.
間を経ても $3 \times 10^{-5} \mathrm{~A}$ と基礎試料のそれより約 2 けた 低い值を示し，熱暴走に至る寿命は著しく改善された ことを示している。しかし， $900^{\circ} \mathrm{C} て ゙$ 熱処理した場合 は, 電圧印加後 10 時間において, 既に基礎試料の漏 れ電流より 2 けた程度大きな電流が流れ，熱暴走に至 る寿命は逆に小さくなり, 熱処理による固体構造の変 化を示唆している。

\section{〈4・2〉電圧-電流特性に及ほす直流前課電の影響}

直流電圧の印加による $\mathrm{ZnO}$ 素子の漏れ電流は, 試 料の熱処理によって著しく異なることが前節で明らか となった。従って，本節では $\mathrm{ZnO}$ 素子の基本的な電 気特性，すなわち電圧一電流特性に及浑す直流前課電 の影響とこれに及ぽす試料の熱処理効果について調へ た。すなわち，基礎試料切よび熱処理試料 $\left(T_{H-T}=\right.$ $\left.600{ }^{\circ} \mathrm{C}\right)$ を対象に, $\langle 4 \cdot 1\rangle$ 節と同じ直流前課電条件 $\left(T_{p s}\right.$ $\left.=90^{\circ} \mathrm{C}, V_{p s}=200 \mathrm{~V}\right)$ で 500 時間前課電を行った。を の後, これら両試料に対して, 試料温度 $30^{\circ} \mathrm{C}$ のと で電圧一電流特性を求めた。その結果を図 4 に示す。 また，直流前課電の影響を明らかにするために前課電 なしの結果も図中に示している。

いずれの試料とも低電界領域における電流はオーム 則を満足し，比較的高䉓界になると電流はショットキ 一効果で支配され ${ }^{(3)}$, 非直線的な急增を示す特性とな っている。この場合，熱処理を施していない基碟試料 のオーム則領域における電流值は, 前課電なし試料に 比べて 2 けた以上も大きくなっている。これに対して 熱処理を施した試料 $\left(T_{H-T}=600^{\circ} \mathrm{C}\right)$ の電流值は, 前 課電の有無にかかわらずほぼ定で，その影響は見ら

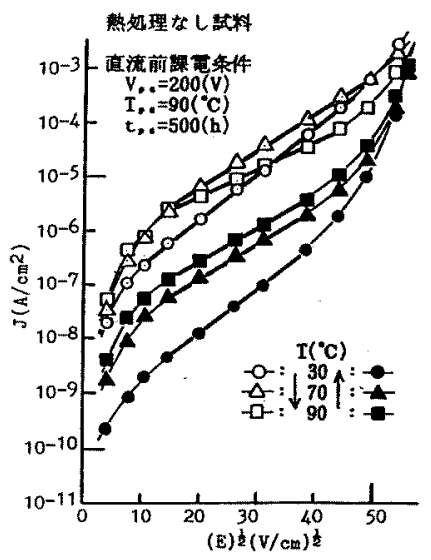

図 5 直流前課電後の $E-J$ 特性の ショットキープロット

Fig. 5. Schottky plot of non-heat treated sample after DC pre-stressing. 
れなかった。

このように基碟試料では，直流前課電によって著し 〈電流值が增大することに着目し, 試料温度をパラメ 一タとして電圧一電流特性を測定した。すなわち, 試 料温度を $30^{\circ} \mathrm{C}$ から $130^{\circ} \mathrm{C}$ まで, 各試料温度ごとに電圧 を高電界領域まで印加し, 電圧一電流特性 $(O, \Delta$ など) を測定した。その後, 引続き試料温度を $130^{\circ} \mathrm{C} か ら$ $30^{\circ} \mathrm{C}$ ま゙逆に低下させ, 各温度ごとに電圧一電流特性 (し、ムなど）を測定した。図 5 はこれらの結果をショ

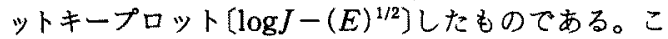
の結果, 試料温度を大きくする過程において, $E-J$ 特性は直流前課電の影響として,ショットキー効果に よる支配領域が高電界領域まで広がっていることが明 らかとなった。

また，図 6 はこれらの基礎試料を対象に，E-J特性 の低電界領域に対して, 導電率 $\sigma(\sigma=J / E)$ のアレニ ウスプロットを行った結果である。その直線の傾きか ら求まる活性化エネルギーは, 直流前課電の有無と試 料温度を増大していく場合と低下していく場合とで変 化することが明らかになった。すなわち，活性化エネ ルギーは直流前課電なしの場合のほうが，前課電した 場合より大きく，また直流前課電した場合でも，試料 温度を高くする過程のほうが，低下していく過程のそ れより小さくなっている。このことは，Zn 粒界層に 形成されたショットキー障壁の高さが直流電圧を前課 電することによって相対的に低くなり，更にその後の 温度を低下きせることによって元の状態に回復したこ とを示唆している。

一方， $600^{\circ} \mathrm{Cで}$ 熱処理した試料のアレニウスプロッ 卜には，このような特性変化は見られず，基礎試料に

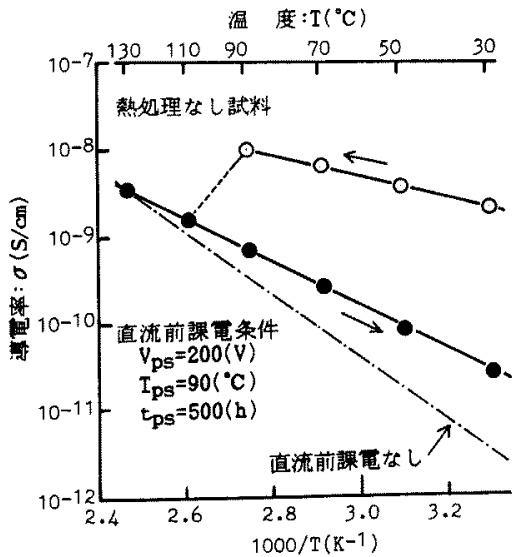

図 6 直流前課電後のアレニウスプロット Fig. 6. Plots of $\log \sigma$ versus $1 / T$ after DC pre-stress.

奄学論A, 111 巻 10 号, 平成 3 年
対するより若干活性化エネルギーの低下が見られる程 度であり，直流前課電の影響をほとんど受けないこと が明らかとなった。

\section{〈4・3〉熱刺激電流に及ぼす直流前課電の影響}

基礎試料と熱処理試料 $\left(T_{H-T}=600^{\circ} \mathrm{C}\right)$ を対象に, 直流前課電なしの場合と $T_{p s}=90^{\circ} \mathrm{C}, V_{p s}=200 \mathrm{~V}$ の 条件で前課電した場合について，試料のエレクトレッ

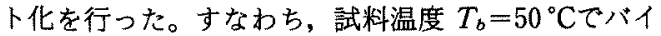
アス電圧 $V_{b}=100 \mathrm{~V}$ を $t_{b}=30 \mathrm{~min}$ 印加した後, 試料 温度を約 $-80^{\circ} \mathrm{C}$ まで急冷して凍結状態とした。そし て，電極間を短絡(図 1 でスイッチ $S$ を $b$ に投入)し， 放電電流が一定となるのを確認してから $4^{\circ} \mathrm{C} / \mathrm{min} の$ 昇温速度で熱刺激電流 (TSC)を測定した。

図 7 (a)，(b)は，それぞれ基礎試料および熱処理 試料 $\left(T_{H-r}=600^{\circ} \mathrm{C}\right)$ について測定した結果で，直流 前課電時間 $t_{p s}$ をパラメータとした TSCの一例であ る。基礎試料 ( ( $\mathrm{a})$ 図]においては, 直流前課電なしの 場合, 特徴的な三つの TSC ピーク $\left(P_{1}, P_{2}, P_{3}\right)$ が観

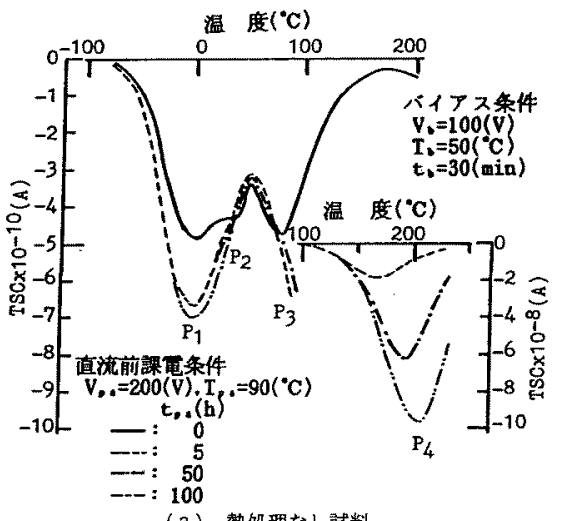

(a) 熱処理なし試料。

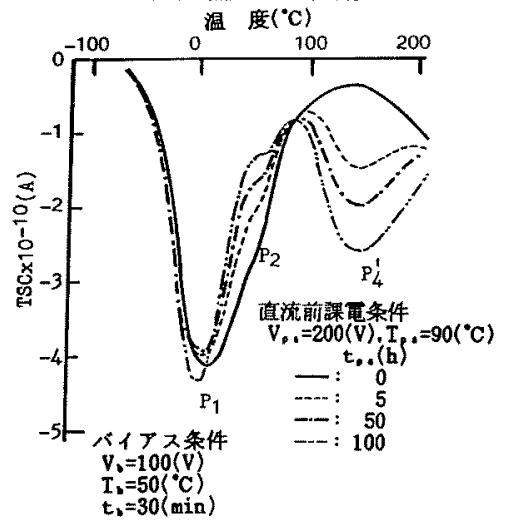

(b) $600^{\circ} \mathrm{C}$ て熱処理をした式粈。

図 7 熱刺激電流の直流前課電時間依存性 Fig. 7. Dependence of TSC on DC pre-stressing times. 


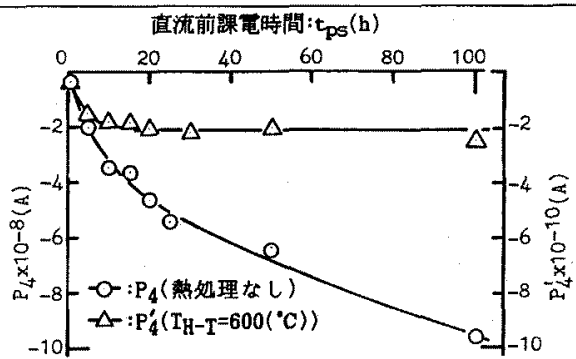

(a) TSCピークの大き

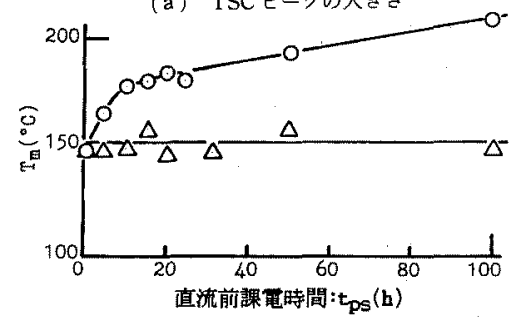

(b) TSCゼークの現れる賉度

図 8 特性 TSC ピーク $\left(P_{4}, P_{4}^{\prime}\right)$ の直流前 課電時間による変化

Fig. 8. Dependence of characteristic TSC peaks $\left(P_{4}, P_{4}^{\prime}\right)$ on DC pre-stressing time.

測された。そのピーク温度はそれぞれ $0,30,75^{\circ} \mathrm{C}$ 近 傍である。前課電を行った場合は, $P_{1}, P_{2}, P_{3}$ 以外 に高温側で新たな $P_{4}$ ピークが観測された。この場合, $P_{1}, P_{2}, P_{3}$ の大きさは前課電時間 $t_{p s}$ に関係なくほほ 一定である。しかし， $P_{4}$ ピークの大きさは，前述の

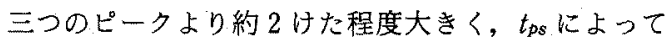
ピーク温度は高温側へ移行すると共にピークの大きさ も增大する特徴を示した。

これに対し，熱処理試料 $\left(T_{H-T}=600^{\circ} \mathrm{C}\right)$ に扔いて は, 直流前課電なしの場合, 基礎試料と同樣に $P_{1}$,

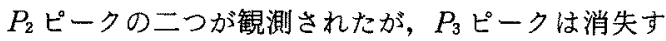
ることが確認された。前課電を行うと $P_{1}, P_{2}$ ピーク は同様に生ずるが，そのピークの大きさは $t_{p s}$ に関係 なくほ浪一定である。また， $150^{\circ} \mathrm{C}$ 付近に $P_{4}^{\prime}$ ピーク が観剆され，その大きさはわずかながら大きくなり飽 和する傾向を示した。この結果をもとに両試料を比較 するとき, 直流前課電なしの場合, 熱処理によって $P_{3}$ ピークが消失し，前課電を行った場合は，それぞ

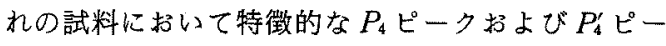
クが観測された。

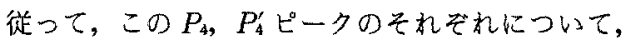
$t_{p s}$ に対するピークの大きさとピーク温度を整理した のが図 8 (a)，(b)である。この結果は，基礎試料と 熱処理試料に対し，直流前課電により高温領域で生じ た特徴的な TSCピーク $P_{4}, P_{4}^{\prime}$ の特性がそれぞれ異 なることなどから， $P_{4}, P_{4}^{\prime}$ ピークの発生に寄与する
キャリヤ種がそれぞれ異質のものであることを示唆し ている。

〈4・4〉直流前課電による $\mathrm{ZnO}$ セラミックスの特性 変化に関する一考察 ZnOセラミックスはn形半 導体である $\mathrm{ZnO}$ 結晶粒が薄い粒界層で取囲まれた微 細構造をしており, 従ってそのエネルギーバンド構造 としては，薄い粒界層を介した対称的な二重ショット

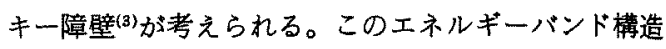
を用いて，直流前課電による $\mathrm{ZnO}$ セラミックスの電 気的特性の変化とそれらに及ほす試料の熱処理効果に ついて考察を加えてみる。

$\mathrm{ZnO}$ セラミックスの電気的特性 (E-J特性, TSC) 㹥直流前課電によって著しく変化し, その程度は試料 の熱処理によっても大きく影響されることが明らかに なった。これらの電気的特性の変化は, 熱処理に伴う $\mathrm{ZnO}$ セラミックスの構造変化に起因していることが 考えられる。

熱処理を施していない試料では， $\mathrm{ZnO}$ 粒間に存在 する絶縁体層の固相 $\left[\mathrm{Bi}_{2} \mathrm{O}_{3}\right.$ 相 $(\beta$ および $\delta$ 形 $)$ 中に $\mathrm{Zn}^{++}$および $\mathrm{Sb}^{+++}$などのイオンの存在が指摘されて いる(4)。これらのイオンは, 高温状態で $\mathrm{ZnO}$ 試料に 直流電圧の前課電によって $\mathrm{ZnO}$ 粒子との界面まで移 動し, そこに蓄積される。この結果, 正イオンの蓄積 した $\mathrm{ZnO}$ 粒界において， $\mathrm{ZnO}$ 粒子の電子に対するポ テンシャルエネルギーは高くなり，すなわち，ショッ トキー障壁の $\mathrm{ZnO}$ 粒子側から見た障壁高さはその分 減少して, 非対称となることが考えられる。その後の $E-J$ 特性の測定においては, この非対称二重ショッ トキー障壁に直流前課電と同方向の電圧を印加するこ とにより，正イオン蓄積層が生じた側の障壁高さは， 更に外部電圧分だけ低下することになる。

すなわち, 順バイアス方向のキャリヤの移動は, 正 イオン蓄積層が生じた側の $\mathrm{ZnO}$ 粒子側から見た障壁 高さで律則されることになる。このようなイオンの振 舞いを考えるとき, 直流漏九電流の增加のほか, 直流 前課電後の電流の急增を定性的に説明することができ る。更に, 試料温度を直流前課電の条件温度 $\left(90^{\circ} \mathrm{C}\right)$ 以 上に高くして $V-I$ 特性を测定するとき, その電流値 は, 先に得た試料温度の低い条件で測定した值より約 1 けた小さく, $V-I$ 特性に特異現象が生じる。この 特異な現象も $\mathrm{ZnO}$ 粒子との界面に蓄積した $\mathrm{Zn}^{++}$, $\mathrm{Sb}^{+++}$イオンが, 試料温度が高くなることによって解 放され, ショットキー障壁高さが回復したと考えるこ とにより定性的に理解でさる。

以上のイオンの振舞いは, TSC $の P_{4}$ ピークの出現 に対応しているものと考えることができる。一方， 
$600^{\circ} \mathrm{C}$ で熱処理を施した試料の直流前課電による電気 的特性は, $\mathrm{ZnO}$ 粒子間に存在する絶縁層の $\beta$ および $\delta-\mathrm{Bi}_{2} \mathrm{O}_{3}$ 相が熱処理によりイオンを含まない $\gamma-\mathrm{Bi}_{2} \mathrm{O}_{3}$ 相に相変態すること(5)を考慮するとき, 前者のそれら とは異なることが理解できる。すなわち, $\mathrm{Bi}_{2} \mathrm{O}_{3}$ 相中 のイオンに起因するショットキー障壁高さの変歪は考 えにくく, 従って, $P_{4}^{\prime}$ ピークは $\mathrm{Bi}_{2} \mathrm{O}_{3}$ 相中などに存在 するトラップに捕獲されたキャりヤに起因することな どが考えられる。

以上の結果, $\mathrm{ZnO}$ セラミックスの電気的特性の直 流電圧印加に対する長時間安定性が, 試料の熱処理に よって改善されることが示唆された。

\section{5. むすび}

$\mathrm{ZnO}$ セラミックスの電気的特性に及ほす直流前課 電の影響と,これに関連する試料の熱処理の効果につ いて検討した。以上の結果を要約すると次のとおりで ある。

（1）熱処理を施していない試料の直流前課電時に 流れる直流漏れ電流は, 電圧印加時間と共に増大する のに対し， $600^{\circ} \mathrm{C} て ゙$ 熱処理を施した試料の直流漏れ電 流は，ほとんど変化を示さないか，あるいは逆に電圧 印加時間と共に減少する傾向を示した。

（2）直流前課電直後の $V-I$ 特性は, 熱処理を施 していない試料では, 直流前課電時間の増加と共に低 下する。また, 直流前課電条件 $\left(90^{\circ} \mathrm{C}\right)$ 以上の温度にす ることにより, 電流值が 1 けた程度低下する $V-I$ 特 性の回復が観測された。このような現象は, $\mathrm{ZnO}$ 粒 間の絶縁層の固相 $\left(\mathrm{Bi}_{2} \mathrm{O}_{3}\right)$ 中に存在するイオンが $\mathrm{ZnO}$ 粒子の界面まで移動し，蓄積されることによるショッ トキー障壁高さの低下とイオンの熱的解放に伴う障壁 高さの回復より考察した。一方, $600^{\circ} \mathrm{C} て ゙$ 熱処理を施 した試料の $V$ - $I$ 特性に及ほすす直流前課電の影響は, 本実験の範囲においてはほとんど観察されず, 直流電 圧に対する長時間安定性を示唆している。

（3）直流前課電流後の熱刺激電流は，熱処理を施 していない試料では, 高温側に新たに $P_{4}$ ピークが観 測された。この TSCピークの大きさは, 直流前課電 時間と共に大きくなり, しかも他の TSC ピークの大 きさに比べ約 2 けた大きい。また，この TSCピーク の現れる温度も直流前課電時間と共に高温側に移行す る傾向を示した。この結果, $P_{4}$ ピークは粒間絶縁層 の固相 $\left(\mathrm{Bi}_{2} \mathrm{O}_{3}\right.$ 相) 中のイオンの振舞いに起因している ものとして考察を行った。一方, $600^{\circ} \mathrm{C} て ゙$ 熱処理を施 した試料の TSCには，直流前課電に伴い約 $150^{\circ} \mathrm{C}$ 付

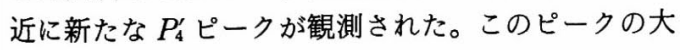

きさは, 前者の $P_{4}$ ピークに比べ 2 けた小さく, しか もピークの現れる温度も直流前課電時間に関係なく一 定であり，トラップに捕獲されたキャリヤに起因する ものと考えた。

以上の結果, $\mathrm{ZnO}$ セラミックスの電気的特性に及 ほす直流前課電の影響は, 試料の熱処理によって著し く変化し, 特に $600^{\circ} \mathrm{C} て$ 熱処理を施すことによって, 直流電圧に対する長期安定性が得られることが示唆さ れた。

最後に, 試料の提供をいただいた日本高圧電気(株) の関係各位に心よりお礼申し上げます。本研究の一部 は「財団法人中部電力基礎技術研究所」研究助成の援 助によって行われたことを付記し，謝意を表します。 (平成 2 年 12 月 25 日受付)

\section{文 献}

(1) 例えば, M. Hayashi, M. Haba, S. Hirano, M. Okamoto \& M. Watanabe: "Degradation Mechanism of Zinc Oxide Varistors under DC Bias", J. Appl. Phys., 53, 5754(1982).

(2) W. Moldenhauer, K. H. Bather, W. Bruckner, D. Hinz \& D. Buhling: "Degradation Phenomena of $\mathrm{ZnO}$ Varistors", Phys. Stat. Sol. (a), 67, 533(1981)

（3）例えば, G. D. Mahan, Lionel M. Levinson \& H. R. Philipp: "Theory of Conduction in ZnO Varistors", J. Appl. Phys., 50, 2799 (1979)

(4) M. Inada: "Effects of Heat-treatment on Crystal Phases, Microstructure and Electrical Properties of Nonohimic Zinc Oxide Ceramics", Japan J. Appl. Phys., 19, 1439(1979)

(5) A. Iga, M. Matsuoka \& T. Masuyama : "Effect of Phase Transition of Intergranular $\mathrm{Bi}_{2} \mathrm{O}_{3}$ Layer in Nonohmic $\mathrm{ZnO}$ Ceramics. ", Japan J. Appl. Phys., 15, 1161(1976)

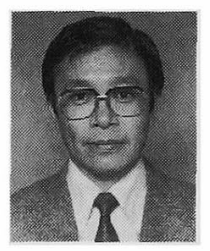

\section{河 村 英 昭 (正員)}

昭和 17 年 10 月 22 日生。 40 年 3 月名城大学工学部電気工学科卒業。 同年 4 月同大学助手, 48 年同講師, 59 年同助教授, 現在に至る。工学 博士。主として, 有機材料の電気的特性に関する研 究に従事。 48 年電気学会論文賞受賞。静電気学会会 員。

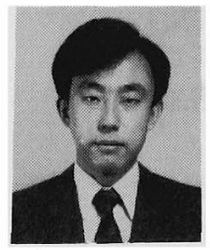

\section{山田勝 久 (准員)}

昭和 40 年 9 月 28 日生。平成 3 年 3 月名城大学大学院工学研究科修士 課程電気電子工学専攻修了。平成 3 年 4 月日本ガイシ(株) 入社, 現在に 至る。 


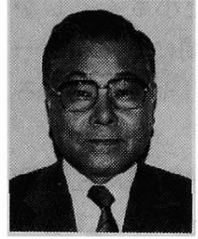

縄田正人 (正員)

昭和 5 年 3 月 30 日生。 30 年 3 月 名城大学理工学部電気工学科卒業。 同年 4 月同大学助手, 42 年同助教 授, 49 年同教授, 平成 1 年同教務 部長, 現在に至る。工学博士。電気絶縁工学(主とし て, 誘電体の高電界電気伝導と絶縁破壊) に関する研 究と教育に従事。この間, 名古屋大学工学部に国内留 学し, 誘電体の絶縁物性に関する研究に従事。 48 年 電気学会論文賞受賞。応用物理学会, 電気設備学会, 電気加工学会会員。

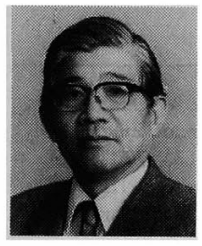

$$
\text { 家田正之 (正員) }
$$

大正 14 年 10 月 8 日生。昭和 24 年 3 月名古屋大学工学部電気工学科 卒業。35 年同大学助教授, 41 年同 教授, 61 年同工学部長。平成元年
愛知工業大学電気工学科教授, 現在に至る。工学博 士。放電物理(主として, 高電界の電気伝導と絶縁破 噮)および誘電体工学, 高電圧工学を総括した電気絶 縁工学に関する研究と教育に従事。 51 年 5 月電気学 会絶縁材料常置専門委員会委員長, 同年 6 月同幹事, 55 年 1 月絶緑材料技術委員会委員長, 60 年 5 月電気 学会副会長を歴任。現在, 14 期日本学術会議会員 (63 年 7 月), CIGRE (SC-15) 日本代表委員。この間, 1 年 8 箇月にわたりアメリカ・コーネル大学 P.デパイ 教授のもとで高電界下の誘電物性に関する研究に従 事。 45 年, 48 年, 52 年, 58 年電気学会論文賞受賞, 55 年同電力賞受賞。電子通信学会, 応用物理学会, 高分子学会, IEEE, CIGRE 会員。 